ISSN: 2162-3104 Print/ ISSN: 2166-3750 Online Volume 6, Number 4 Oct/Nov (2016) pp. I-V

(C) Journal of International Students http://jistudents.org/

\title{
Campus Readiness for Supporting International Student Success
}

\author{
Rahul Choudaha \\ DrEducation, USA
}

\begin{abstract}
American higher education is among the most preferred destinations for many globally mobile students. According to OECD (2016), the United States is the leading destination attracting $26 \%$ of all the globally mobile students followed by the United Kingdom (15\%), France (11\%), Germany $(10 \%)$, and Australia ( $8 \%)$; yet the share of international students in the total enrollment at the tertiary level in the U.S. is only $4 \%$. One of the primary reasons for the attractiveness of American institutions is the perception of quality education among prospective students and its implications for a better career and life success. The terror attacks of September 11, 2001 resulted in a temporary decline in international student enrollment, which continued until 2005/06. Since then American higher education has shown resilience and the enrollment of international students has been growing at a healthy pace. Between 2001/02 and 2014/15, the number of international students in U.S. universities and colleges increased by $67 \%$ to reach nearly 974,926 students (Open Doors, 2015). However, source countries and destination institutions skew this growth. For example, international students from the leading 10 places of origin grew by $121 \%$ and likewise, the leading 10 institutions of international student enrollment increased by 166\% (Open Doors, 2015).

Global financial recession of 2007/08 was one of the reasons that contributed to the skewed growth. The recession compelled many institutions, including some of the top-ranked institutions, to aggressively expand international student enrollment. This growth pressure was even more pronounced in the American public institutions of higher education. For example, international student enrollment at 13 leading public research universities, which are part of the Big Ten Academic Alliance, grew by only
\end{abstract}


$16 \%$ between $2001 / 02$ and $2007 / 08$ as compared to $74 \%$ between $2007 / 08$ and 2014/015.

Table 1: International Student Enrollment Growth Post-9/11

\begin{tabular}{|l|r|r|r|}
\hline & $2014 / 15$ & $2001 / 02$ & $\begin{array}{c}\text { \% Change (2001/02 } \\
\text { to 2014/15) }\end{array}$ \\
\hline $\begin{array}{l}\text { Students from Leading 10 } \\
\text { Places of Origin }\end{array}$ & 687,329 & 310,947 & $121 \%$ \\
\hline $\begin{array}{l}\text { Leading Places of Origin as } \\
\text { a \% of Total Enrollment }\end{array}$ & $71 \%$ & $53 \%$ & \\
\hline $\begin{array}{l}\text { Students at Leading 10 } \\
\text { Institutions }\end{array}$ & 106,754 & 40,180 & \\
\hline $\begin{array}{l}\text { Leading 10 Institutions as a } \\
\text { \% of Total Enrollment }\end{array}$ & $11 \%$ & $7 \%$ & $166 \%$ \\
\hline Total Enrollment & 974,926 & 582,996 & $67 \%$ \\
\hline
\end{tabular}

\section{IMPLICATIONS OF SKEWED GROWTH}

This dramatic and skewed growth has implications for international student success. It has exposed the lack of readiness of many campuses to engage and support international students. Many large campuses which already had significant international student populations were unsure and unprepared about how to manage the expectations of campus and community stakeholders in working with the rapid growth of international students on the campus. Likewise, many small to medium-sized campuses, which were new to recruiting international students were not able to invest in and scale up corresponding infrastructure, resources and competencies needed to support international students.

The American Council on Education in its 2012 report identified that, "While efforts to recruit international students are on the rise, the data do not show a commensurate increase in support services for these students" (p. 5). Likewise, Green (2013) asserts that "...too many institutions have ramped up their goals without planning for the accompanying investment in student services, language support, or programs to facilitate integration into the local and campus community" (p. 53). Driven by financial pressures and limited resources, some institutions are charging or additional fees applicable only to international students (Redden, 2015).

At many campuses, support services for international students only address immigration and visa compliance. International students need, deserve, and want more in terms of academic and career support. For example, mismatch in expectations of career advancement prior to 
enrollment and their actual experience on campus is one of the key reasons mentioned by international students regarding their dissatisfaction on American campuses (Choudaha \& Schulmann, 2014).

By continuing to increase tuition and fees for international students without a proportionate reinvestment in the success of the students themselves, some institutions are behaving contrary to their missions, values and principles. Green (2013) asks, "To what extent do our practices in recruiting and providing a positive educational and social experience for international students align with the values and principles we articulate?" (p. 2). Likewise, Özturgut and Murphy (2009) concluded that U.S. institutions “... are not 'practicing what they preach' when it comes to meeting the needs of international students. They are not using the research to drive practice in accommodating international students" (p. 374).

\section{IN SEARCH OF SOLUTIONS}

It's high time to stop treating international students as cash cows and embrace the values which institutions expect their students to manifest. To build a sustainable and an inclusive model of enrolling and integrating international students with local students and campus communities, institutions of higher education must invest in campus readiness. Glass, Buss, and Braskamp (2013) note that "It is imperative that institutions devote more attention (and perhaps also more resources) to this surprisingly neglected, though powerful, student demographic" (p. 44).

Many colleges and universities are missing the opportunity of investing in their students who later become their brand ambassadors. According to Lee (2010), "The perception of receiving fair and equal treatment was the most important influence leading a student to recommend the host university to others, followed by satisfaction with institutional services and the university's reputation" (p. 76).

Institutions must proactively diversify international student body by investing in recruitment efforts that take time to cultivate new markets and attract different segments of students. Creating an inclusive campus climate requires not only providing adequate tools and resources but also building intercultural competence among diverse stakeholders including faculty, administrators, and students-domestic and international. Knowledge is only one part of the intercultural competence the other two parts are skills and attitudes. Many faculty and administrators know the need of intercultural competence, however practicing it with skill and a welcoming mindset is yet to be achieved on many campuses.

To continue the leadership of the United States as the number one destination among globally mobile students, institutional leaders (both at the 
policy and program levels) would require proactive investment of time, talent and effort to define and deliver outcomes related to international students' academic and career success.

\section{SPECIAL ISSUE}

The aim of this special issue is to advance the research agenda about the needs, experiences and expectations of international students so that research can help build institutional readiness for supporting academic and career pursuits of international students. This special issue includes a collection of 18 articles from 32 authors. They address several research concerns related to international student success including leadership selfefficacy, writing proficiency, mentorship, retention, student satisfaction, sense of belongingness, plagiarism, and career services.

I am thankful to the leadership and commitment of Dr. Krishna Bista, founder and editor-in-chief of the Journal, for providing this opportunity of editing the special issue. I appreciate the contributions of the authors and reviewers and we hope that this issue will further advance the awareness and actions needed in making campuses ready to support international students.

\section{REFERENCES}

American Council on Education. (2012). Mapping internationalization on U.S. campuses.

Bista, K., \& Foster, C. (eds.). (2016). Campus support services, programs, and policies for international students. Hershey, PA: IGI Global.

Bista, K., \& Foster, C. (eds.). (2016). Exploring the social and academic experiences of international students in higher education institutions. Hershey, PA: IGI Global.

Bista, K., \& Foster, C. (eds.). (2016). Global perspectives and local challenges surrounding international student mobility. Hershey, PA: IGI Global.

Choudaha, R. \& Schulmann, P. (2014). Bridging the gap: Recruitment and retention to improve international student experiences. NAFSA: Association of International Educators.

Glass, C. R., Buus, S., \& Braskamp, L. A. (2013) Uneven experiences: What's missing and what matters for today's international students. Chicago: Global Perspective Institute.

Green, M. (2013). Acting as global citizens: A challenge to U.S. colleges and universities. NAFSA International Educator.

Lee, J. J. (2010). International students' experiences and attitudes at a US host institution: Self-reports and future recommendations. Journal of Research in International Education, 9(1), 66-84. doi: 10.1177/1475240909356382 
Özturgut, O. \& Murphy, C. (2009). Literature vs. practice: challenges for international students in the U.S. International Journal of Teaching and Learning in Higher Education, 22(3), 374-385.

OECD (2016). Education at a glance. Paris: OECD Publishing. http://dx.doi.org/10.187/eag-2016-en

Redden, E. (2015, May 8). Fee for being foreign. InsideHigherEd.com. Retrieved from https://www.insidehighered.com/news/2015/05/08/some-publicuniversities-are-charging-differentiated-tuition-rates-or-raising-fees

Ting, R. S., \& Morse, A. (2016). 5 things student affairs professionals can do to support international students. NASPA - Student Affairs Administrators in Higher Education.

RAHUL CHOUDAHA, $\mathrm{PhD}$, is the principal researcher of DrEducationa U.S.-based research and consulting firm. He co-founded interEDGE.orga social venture focused on inclusion and success of international students. Dr. Rahul Choudaha advises, speaks, researches and writes on internationalization trends and insights with a focus on international student enrollment and experiences. Choudaha is a recipient of the Tony Adams Award for Excellence in Research from the European Association of International Education for his research on international student segmentation. He serves as a member of the Editorial Board of The Journal of Studies in International Education. He served on the chair-stream of International Education Leadership Knowledge Community for NAFSA: Association of International Educators. Choudaha holds a doctorate in higher education, a master's in management and a bachelor's in engineering. Email: Rahul@DrEducation.com 